\title{
難聴児早期発見のためのスクリーニング検査の検討
}

\author{
加藤 寛・九鬼佐代子・田端 敏秀

\section{Screening for Early Detection of Hearing-impaired Children}

\author{
Yutaka Katoh, Sayoko Kuki and Toshihide Tabata \\ (Wakayama Medical College)
}

The historical aspect of the progress of screening test for detection of hearing impairment during the fetal stage, neonatal stage, infantile stage and early childhood $(2 \sim 4$ years of age) is reviewed.

The method using intra-uterine sound introduced here is quite useful for detection of hearing loss in the neonate stage. In addition, the role of auditory brainstem response in early detection of hearing-impaired children was described in detail.

Conclusively, an infant hearing screening program was proposed for the public health centers, that is an intra-uterine sound method, auditory eye opening response at falling into sleep using a tongue-clicking sound, a developmental test of auditory function and identification of risk factors associated with hearing loss.

Key words: hearing-impaired children, early detection, intra-uterine sound, screening tests

\section{緒言}

近年情報化社会のめざましい発達とともに難 聴児の早期発見, 診断ならびにハビリテーショ ンの重要性が広く一般社会にも認識され，耳鼻 咽喉科医や教育関係者にたいしてこの分野の充 実が望まれるよらになってきた。このよらな社 会的要請に応えるべく耳鼻咽喉科領域において も以前より先輩諸氏が難聴児早期発見のため各 種之クリーニング検査の開発に努めより簡便で 信頼性の高い聴力検査法の成立を目標に努力し てきた。しかしこの分野におけるスクリーニン グ検査の体系は未だ整ってはいず診断学も確立 されている状態とは言えない。

今回我々は難聴児スクリーニング検査法の発
達の歴史を振り返り, 現在一般的に使用されて いる幼児聴力検査法につき我々の方法成績をる まえ概説するとともに今後のあるべきシステム 化の姿についても考学てみることにした.

I . 時期別によるスクリーニング検査の種類 (1) 胎児期

中耳や内耳は胎生 5 力月には成人と同じ大き さにまで発達して蝸牛機能も活動し始めてい る112) ことより, 音刺激に対する胎動の自覚344) や, 胎動の記録5), 胎児心拍数の变化の記 録(16)7), 誘発反応の記録819) などの報告がある10). しかしこの時期の難聴児スクリーニング検査の 試みについては今まで報告はなく, 将来実現す る可能性は少ないと思える。 
（2）新生児期

この時期においては，音源を用いて聴性行動 反応 $(\mathrm{BOA})$ を観察することにより被験児の聴 力の有無を判断する，つまり音刺激によって誘 発される Moro 反射, 眼瞼反射, 覚醒反射, 瞬 目反射などの皮質下で統合された無条件反射に より難聴を診断する11) 方法がとられている. これらの方法では $70 \mathrm{~dB}$ 以上の音刺激を呈示す るのが常である.

この時期のスクリーニング検査の試みは Ewing12) (1944) に始まり, Hardy'13)14) (1959, 1962), Fröding (1960）の報告15) を経て有名な Downs ${ }^{1617)}(1964 ， 1967)$ の歴史的発表へと進ん でくる. Downs ${ }^{17)}$ (1967) は主として $3000 \mathrm{~Hz}$ 中心とした白色雑音発生装置と, $3000 \mathrm{~Hz}$ の純 音を中心周波数とした wable tone を使用して 分婏入院期間中の新生児全員に組織的なスク リーニング法を施行することを提唱した。この 一定の音源を用いた方法は今日のスクリーニン グ検査の基礎となっている.その後 Goldstein ${ }^{18)}$ (1971) や Shapiro ${ }^{19)}$ (1974) がこの方法を追試し， またわが国においてもこの Downs 法の原理に 則って高島ら ${ }^{20)}$ (1968), 高木ら 21) (1970), や 田口10)（1972）がスクリーニング検査を実施し てきた. しかしその後この方法はスクリーニン グ検査としては著明な発展を見せてはいない。 その理由につき鈴木ら 22)（1979）は(1)進行性難 聴や軽度および中等度難聴が選別されない，(2) 観察される反応は皮質下で統合された反射であ るため, 聴覚系の大脳皮質レベルが正常である かどらかはこの検査では分からない. (3)各検者 による検査の判定が必ずしも一致しない. (4)先 天性難聴の出現頻度はきわめて低く, 生産性が 低いため検査のモチベーションを持続しがだ、 などによると述べている.

以来この時期のスクリーニング検査について は分婏入院期間中を利用して，すべての新生児 をチェックする皆悉検査がよいか，リスク児中 心法で進む注らがよいかが, 様々な視点から検 討されてきた。この両者における欠点を以下に
述べてみる，皆悉検査においては先天性難聴児 の出現頻度は 1 万児につき数名 ${ }^{15)}$ と非常に少 ないため検出率が低くモチベーションの持続が 困難である事や，経済性に問題が有ることであ る、またリスク児のみを対象とした場合にはリ スクを持っていない児，つまり原因不明の難聴 児を取りこぼす可能性がある.これらのことを 考慮に入れたらえで現在の世界的動向はなおり スク児中心検査をしているのが現況である.

この場合のリスク児とは次ぎに列挙するもの である。

(1) 家族歴に遺伝性難聴のあるもの.

(2) 風疹ないし非細菌性の子宮内胎児感染例.

(3) 耳鼻咽喉科領域に奇形のあるもの.

(4) 生下時体重 $1500 \mathrm{~g}$ 以下のもの.

(5) 血清ビリルビン值 $20 \mathrm{mg} / \mathrm{dl}$ 以上のもの.

また1974年の Nova Scota（カナダ）の Halifax で開かれた難聴児早期発見に関する国 際会議でも上記の “five-point high risk register”を中心にスクリーニングを進めるべ きことを勧告している22).

しかしリスク児中心法はあくまでも満足され るべき皆悉検査法が確立されるまでの暫定的な ものであり, 皆悉検査が能率的に簡便により経 済的に実施できるよう研究が進められねばなら ない。このような意図のもとに我々は「泣いて いる新生児に胎内音を聴かせると泣き止む.」 といら反応に注目しスクリーニング検査に使え ないか研究してきた。この検査は胎内音発生装 置を内臓した人形“対んころりん”を用い図 1 のごとく実施する．この音源は $1 / 3$ オクターブ バンド $400 \mathrm{~Hz} \sim 4 \mathrm{kHz}$ に主な周波数領域を持 つ warble tone である（図 2 ). 反応陽性の場 合には（図 3 ）のごとく泣いている児（A）が 劇的に泣き止み alert inactivityになり（B）非 常に分かり易い。これを152児に実施した結果, 新生児期に 2 名の高度難聴児を検出し，またこ の検査が ABR の結果ともよく一致していると の結論をえた23). 表 1 は胎内音反応陽性児の音 圧レベルを示す，表 2 には被験児の $90 \mathrm{dBSPL}$ 
における反応の時期別割合を示したがこのよう に生後 1 力月まで典型的な反応を呈する。これ よりこの胎内音を使っての検査は生後 1 力月以

表 1 胎内音反応陽性と音圧レベル

\begin{tabular}{c|c|c|c}
\hline \hline 童压レ゙゙ル & 約80dB & 約90dB & $90 \mathrm{~dB}$ 以上 \\
\hline 人数 $(\%)$ & $30(20 \%)$ & $103(70 \%)$ & $15(10 \%)$
\end{tabular}

表 2 胎内音 (90 dBSPL) 飞対し alert inactivity 飞 なる被験児の時期別割合

\begin{tabular}{ccccc}
\hline \hline & $\begin{array}{c}\text { 青後 } \\
1 \text { 週問内 }\end{array}$ & 1 ケ月 & 2 ケ月 & 3 ヶ 月 \\
\hline 人数 & $15 / 15$ & $15 / 15$ & $6 / 15$ & $\% / 15$
\end{tabular}

$\begin{array}{lllll}\% & 100 & 100 & 40 & 0\end{array}$

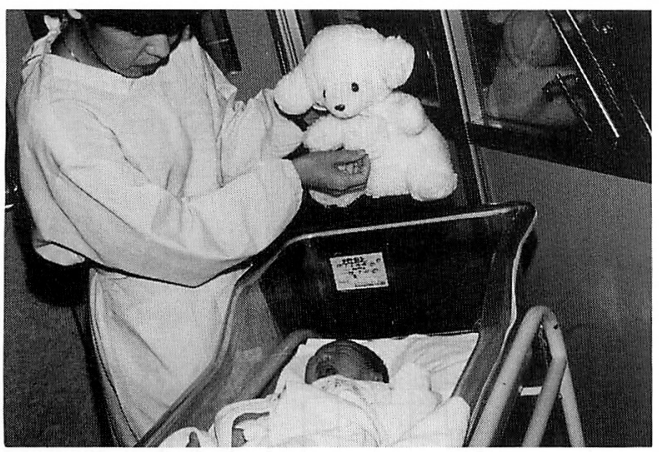

図 1 胎内音発生装置“小んころりん”を用いての 検査
内に実施されることが望ましい24)。このテスト は聴力検査に無縁の素人にも簡単に施行でき, 反応の有無の判定が非常に容易なため, 分娩入 院期間中に出産児全員になされることが可能で ある、またこれを他の検査（舌打ち音，フォイ ッスル音, 紙もみ音に対する反応）と比較して

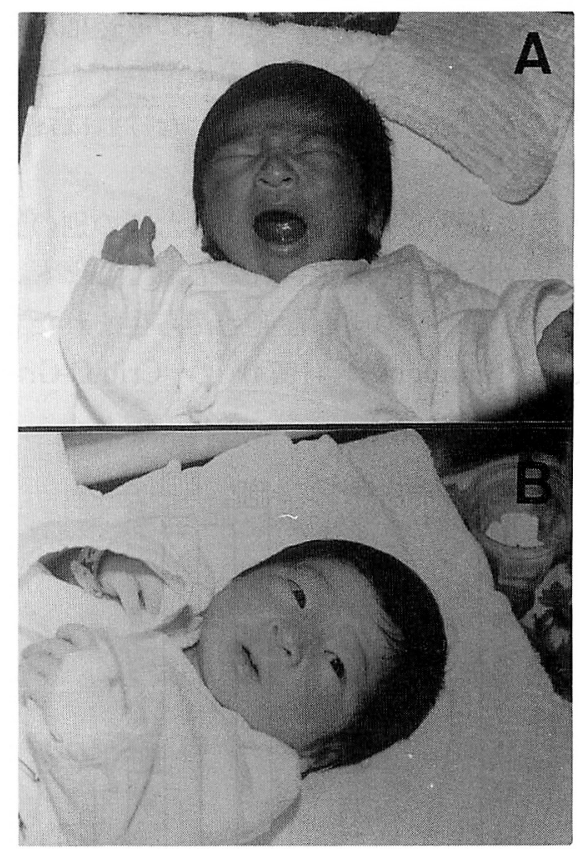

図 $3 \mathrm{~A}$ : 渧泣時, $\mathrm{B}$ : 胎内音に反応し泣き止んだと ころ

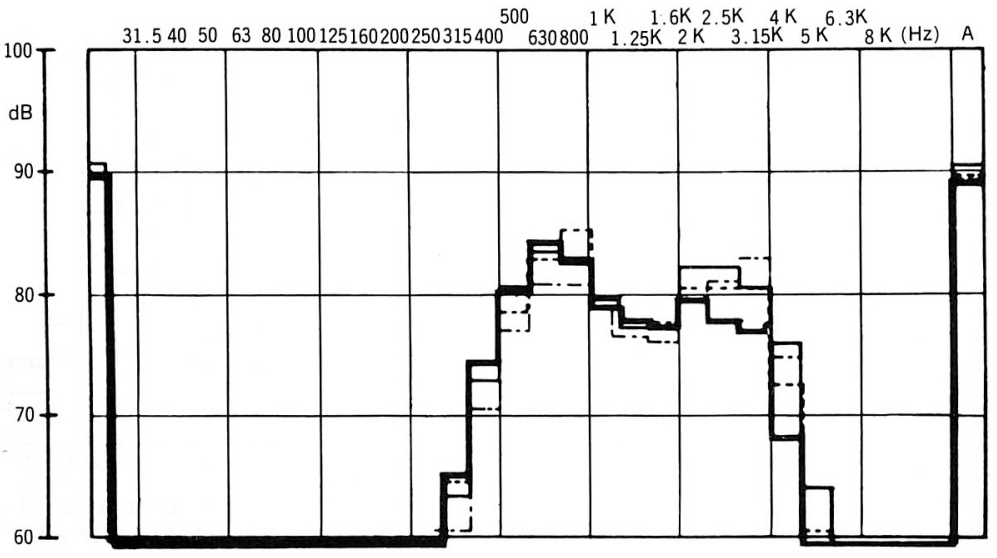

図 2 胎内音の周波数分布 
保健婦が新生児初回訪問時に実施したところ検 査者が反応不明とする割合が有意に少なく（図 4 ） 25) 今後各産科施設への啓蒙活動を広めれば 皆悉スクリーニング検査となり得るとの確信を 持っている。なおこの反応に执いてはその潜時

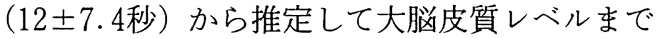
の関与も考号れれ興味深く思っている。しかし この検査は高度難聴児の検出にのみ適応がある という点，また進行性難聴児も漏れてしまう可 能性があるといら点には注意しなければならな い.

皆悉検査への可能性を高めるための別の観点 に立てば検査が能率化されるといらことも大切 な事である。そのよらな発想から生まれた方法 として Simmons' ${ }^{26)}$ (1974) の Crib-O-Gram,
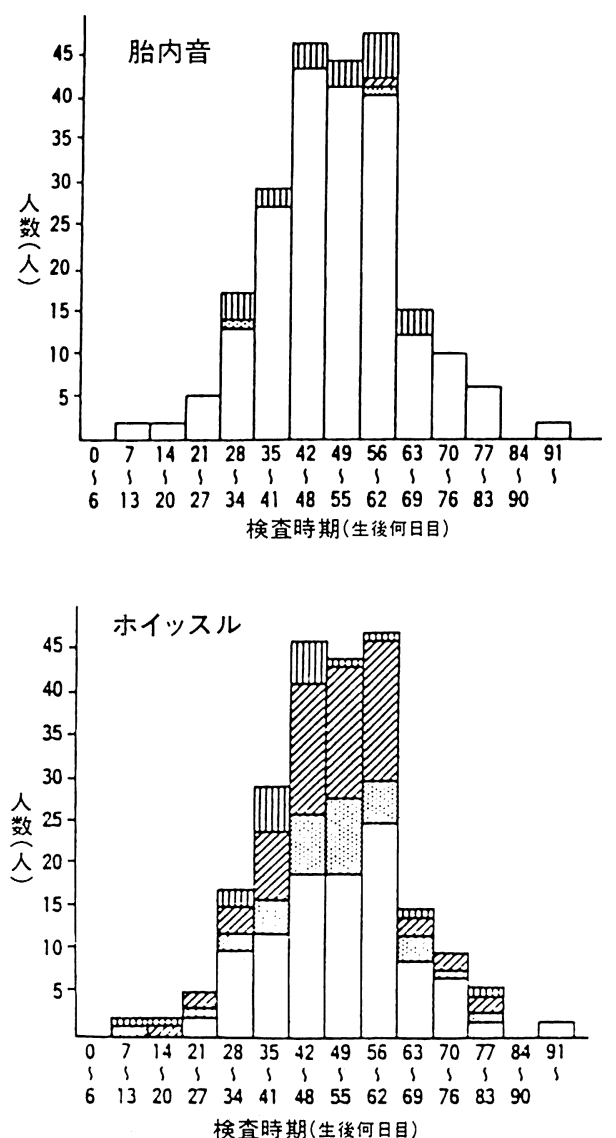

Altman ら 27)（1975）の半他覚的新生児スクリー ニング法や田中ら ${ }^{28)}$ （1983）の半自動的検查装 置 (neonatal audiometer : RION K. K., FD-02) が開発されてきた. Crib-O-Gram はわが国で も販売されており，山本 ${ }^{29330)}(1981 ， 1985 ）$ は その使用経験から 1,510 人中 6 人の難聴児を早 期に検出することに成功しているが，検査に要 した時間は 1 人当たり 45 分から 5 時間 45 分の間 と当初の予想よりも時間を要し，皆悉検査とし てょりもむしろリスク児を対象にこの装置を使 用すれば目的を達成できるであろうとの結論を 導き出している. Altman ら 27)（1975）の方法 の評価についてはあまり検討されていないので 言及できない. neonatal audiometer の評価に 関しては未知数であるが皆悉検査への道を開く
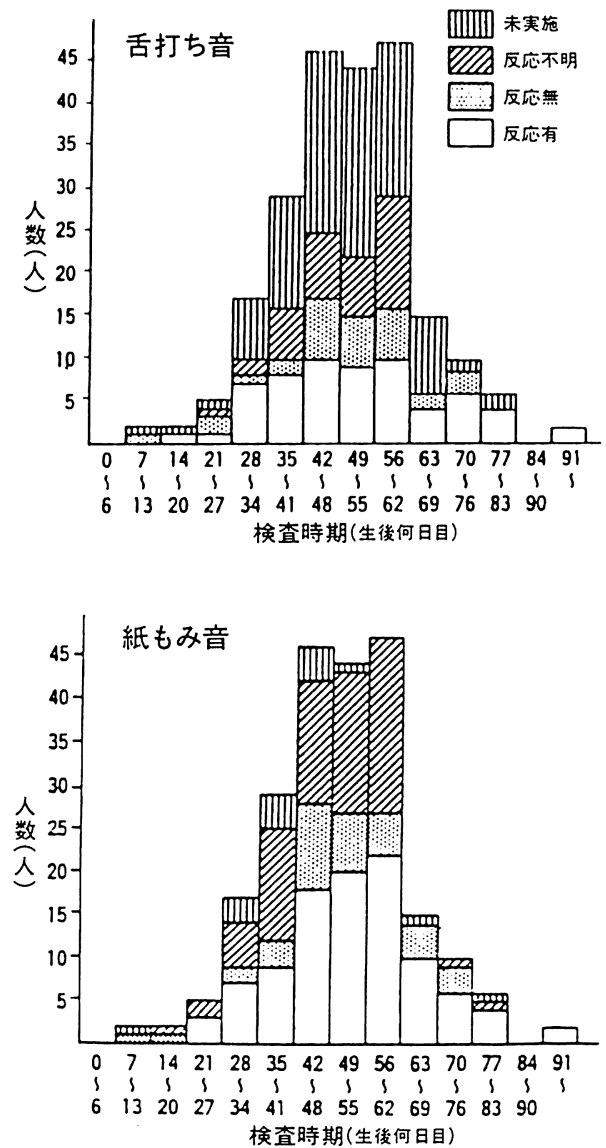

図 4 各検查に対する訪問時期（生後日数）別の反応 
可能性が高い検查法として期待されている。 こ の装置を用いた検查結果の今後の発表が待たれ る.

他にこの時期にも実施できる検査として最も 信頼性が高く客観的判断の可能な聴性脳幹反応 検査がある.これは検査される周波数領域が狭 く装置の経済性や検査に必要な時間が掛かりす ぎる等のことよりスクリーニング検査には不向 きである。しかしこの検査が難聴児の早期発見 に貢献した役割は図り知れない，幼児聴力検査 を論じる上でこの検査を無視して通るわけに行 かず別に主題を掲げて詳述する。

（3）乳幼児期

この時期の難聴児検出法としては鈴木ら31) （1980）の舌打ち音による入眠時開眼反応法,

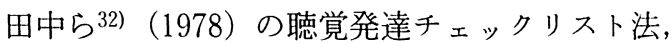
Junker ら ${ }^{33)}$ (1978）の BOEL test によるもの, Teddy-bear screening audiometry, 玩具やセ ロファン紙を用いる方法などがある221.

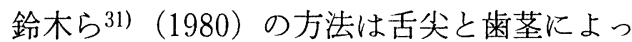

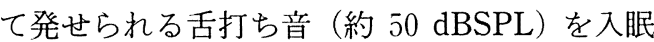
時に与え開眼反応の有無をみるものである。こ の反応はすべての年代に実施可能であるとのこ とであるが，その音圧を考虑すれば乳幼児期か ら以後の検査に適していると思える．この検査 の長所は器具が不要なこと, その指導の仕方次 第で母親も行えるといらこと，また中等度難聴 児もスクリーニングできることである.

聴覚発達チェックリストは 0 力月児から 15 力 月児までの間の各時期に正常児にみられる特徵 的な聴性行動を45項目にリストアップしてある。 これを母親に渡し各家庭で，その時期ごとにチ ェックしてもらうのが田中ら ${ }^{32)}$ (1978）の方法 である。

BOEL test は7〜9カ月児を対象としており木 製の把持棒，銀製スピナ，指輪つき鈴 4 個を使 って視覚的, 触覚的, 聴覚的注意力を調べるも のでュミュニケーション障害を多面的に捕える ことができる34222).

Teddy-bear screening audiometry
$1000,4000 \mathrm{~Hz}$ に中心周波数を持つ warble tone を刺激音とし音圧はそれぞれ40，60，80 $\mathrm{dB}$ で検査ができるようになっている．宮崎 ら35（1969）によれば静かな部屋で実施すれば 生後 7 力月以降では $60 \mathrm{~dB}$ (SPL) で90\%以上の 児に反応がみられるよらになるとのことである。 この方法の原理は条件詮索反応聴力検査 $(\mathrm{COR})^{36)}$ や聴性行動反応検查と同じものであ る. 玩具やセロファン紙を活用しての方法では 用具は安価で入手が容易であり，そのうえどこ ででも使用できるといら手軽さがあるがその検 査音の周波数帯域を知っていなければならない， また音源が広い周波数を含んでいることが多く 狭帯域の難聴児を見逃す可能性が高いことを十 分に理解しておかなければならない。

(4) $2 \sim 4$ 歳児

この年㱓になると急性中耳炎の発症が多く, それに伴って滲出性中耳炎も問題となってくる。 この時期からはインピーダンスオージオメト リーの值も信頼できるようになるのでこの検査 が有効となってくる．しかし古賀37）（1983）は きこえのスクリーニング検査はこの年齢では最 も難しいと述べている．その理由は 2 歳以上で は聴力検査は自発的応答または音に対する反応 的行動によって検査されるが，2・3 歳ではそ のような検査をスクリーニングとして扱らには 困難を伴らからであるとしている．

この時期の検査として知られているのは単語 による選別検査である，万法は単語を用い，絵 カードを見せて，単語に相当するカードを指示 させるといらものであり，野中ら ${ }^{38)}$ (1982）や 長谷川ら ${ }^{39)}$ (1976）がこの様式を踏襲した聴力 検査を試みた結果を報告している.

しかし難聴児の早期発見, 早期診断の理念か らすればこの時期ではすでに遅く，もはやこの 時期の難聴児は言語発達の遅滞を来たしてしま っているといら現実が存在する為に新生児期や 乳幼児期程にはスクリーニング検査の研究発表 がなされていない. 


\section{II．聴性脳幹反応による幼児聴力検査}

(1) 発達による波形の变化

聴性脳幹反応 $(\mathrm{ABR})$ の波形の成熟は生後日 数よりも conceptional age に関係するといわれ る40).

Galambos ら ${ }^{41)}$ (1978), Hecox 5 ${ }^{42)}$ (1982) は未熟児で検査をした結果, 在胎週数26〜28週 で成人域値より約 $70 \mathrm{~dB}$ 大きい音で $\mathrm{ABR}$ が観 察されたと述べている. Starr ら43)（1977）は conceptional age 24〜28週の未熟児 4 人のらち 3 人で $75 \mathrm{~dB}$ クッック対する反応が得られた と報告した。聴器の完成は胎生 6 力月頃とされ ており，ABR の出現もほぼ同時期と思われる. 反応域值は次第に下降し，Lary 5 ${ }^{44)}$ (1985）の 報告によれば，在胎週数28～34週の新生児では $40 \mathrm{~dB} ， 35 \sim 38$ 週では $30 \mathrm{~dB}$ ，正期産のもので は $20 \mathrm{~dB}$ 以内に反応がみられたという．正常新 生児の反応域値についてはその他に Kaga ら ${ }^{45)}$ （1980）は $32 \mathrm{~dB}$, Mokotoff ら46)（1977）は 10 $\mathrm{dB}$, Morgan ら47)（1987）は $35 \mathrm{~dB} て ゙ 99 \%, 25$
$\mathrm{dB} て ゙ 84 \%$ に応が認められたと報告した。成 人よりは域值はやや高いようである.

未熟児では各波ピークの分離もはっきりして おらず（図 5 )，潜時も著明に延長しているが， 成長につれて波も分化し潜時短縮が起こって来 る 47) 51). 潜時の短縮は生後 $1.5 \sim 2$ 歳頃まで続 くといわれている. 出生後波形の変化は生後 2 週までが最も大きく，I 波の潜時は生後 3 力月 までに成人に近付き， $3 \sim 6$ 力月には I-III波 間潜時が短縮し，その後はIII-V波間潜時が短 縮していく49)．1.5～2 歳になり成人の波形に 近付いてくる. 潜時の短縮は潜時の短い波より 起こっており, 聴覚伝導路の成熟は, caudalrostral に進むと考えられる.

（2）ABR による聴力の推定

図 6 に難聴児の ABR を示す. 本例は胎内音 による検査で難聴が発見された例である.

現在 ABR の刺激音として最も広く用いられ ているのはクリックである. クリックは音の立 ち上がりが急峻であり反応が誘発され易いとい

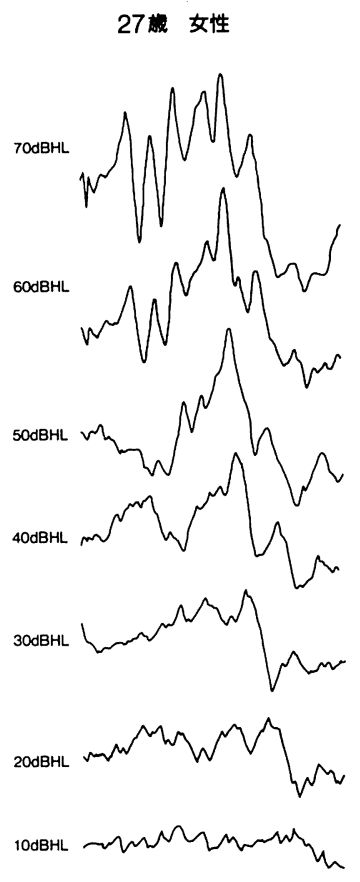

(a)
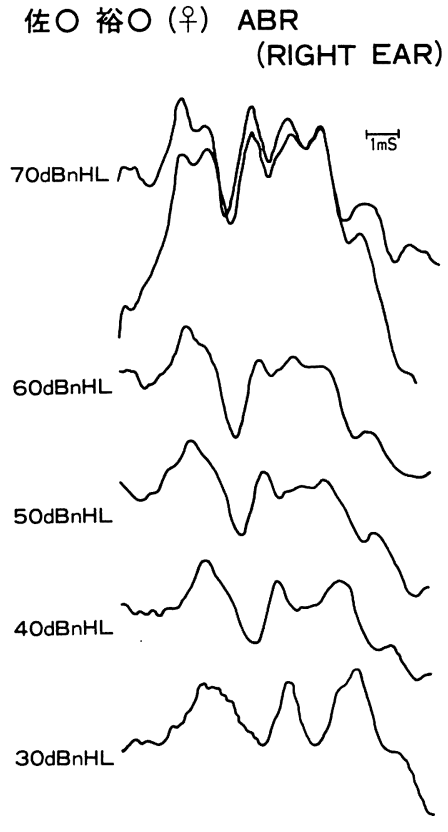

(b)

図 5 成人 (a) 新生児 (b) の ABR 
ら利点がある. 電気的矩形波を用いる場合とサ イン波 I 波を用いる場合があるが，出力側では どちらも周波数選択性の少ない音となる.

従来, クリックによる $\mathrm{ABR}$ 域值は純音の 2 $\sim 4 \mathrm{kHz}$ の聴力を反映しているといわれている. 高瀬52（1987）は ABR のV波域值と 1，2，4 $\mathrm{kHz}$ の純音平均聴力を比較し, 高音急墜型, 水平〜高音漸傾型において両者が相関している ことを示した．また，船井ら53）（1986）は種々 の聴力型の内耳性難睍患者で $\mathrm{ABR}$ 域值が $1 \sim 8 \mathrm{kHz}$ のらち最も感受性の高い周波数の純音域值を反 映すると述べた.

このよらにクリックを用いた ABR は比較的 高音域の聴力と相関するので低音障害型難聴の 場合に ABR 域值が低く出やすいし, 低音域に 残聴がある場合でもそれが検出されにくいとい ら問題が出てくる. そのため, より高い周波数 選択性が期待できる tone pip, tone burst も刺 激音として用いられることが多くなってきてい る. tone pip を用いた ABR の波形はクリック によるものと比べ，各ピークが明らかではなく，
ゆるやかな陽性変動を指標とするものである. その反応の潜時は周波数が低い注ど遅く，また 刺激音強度の減少にともなら潜時の延長も周波 数が低い汪ど大きいといら ${ }^{54)}$. 各周波数の潜時 は，それぞれの刺激音が蝸牛基底板上の蝸牛小 分画まで到達するまでの時間に相当すると考兄 られる55).

Suzuki ら 56)（1977）は 500〜 4000 Hz で反応 域值は大部分が $10 〜 20 \mathrm{dBSL}$ だったと報告し た.また小寺ら54（1977）は正常成人で 500, 1000, $2000 \mathrm{~Hz}$ tone pip で ABR 域值は 10 20 dBSL であり, 高音障害型, 低音障害型難聴例 でも ABR 域值と純音域值が相関したと述べた。 加えて幼少児に执いて $\mathrm{ABR}$ 域值と COR また は遊戯聴力検査域值とも相関を認めた ${ }^{57)}$. 大西 ら58（1983）も同様の結果を発表している.し かし tone pipによる ABR ですべて良好な周波 数選択性がえられるかといらと，そういら報告 ばかりではなく, Hayes ら59)（1982）は高音障 害例では $500 \mathrm{~Hz}$ で純音域值よりも高くなりや すいといわ机，また堀内ら60)（1988）も聴力図
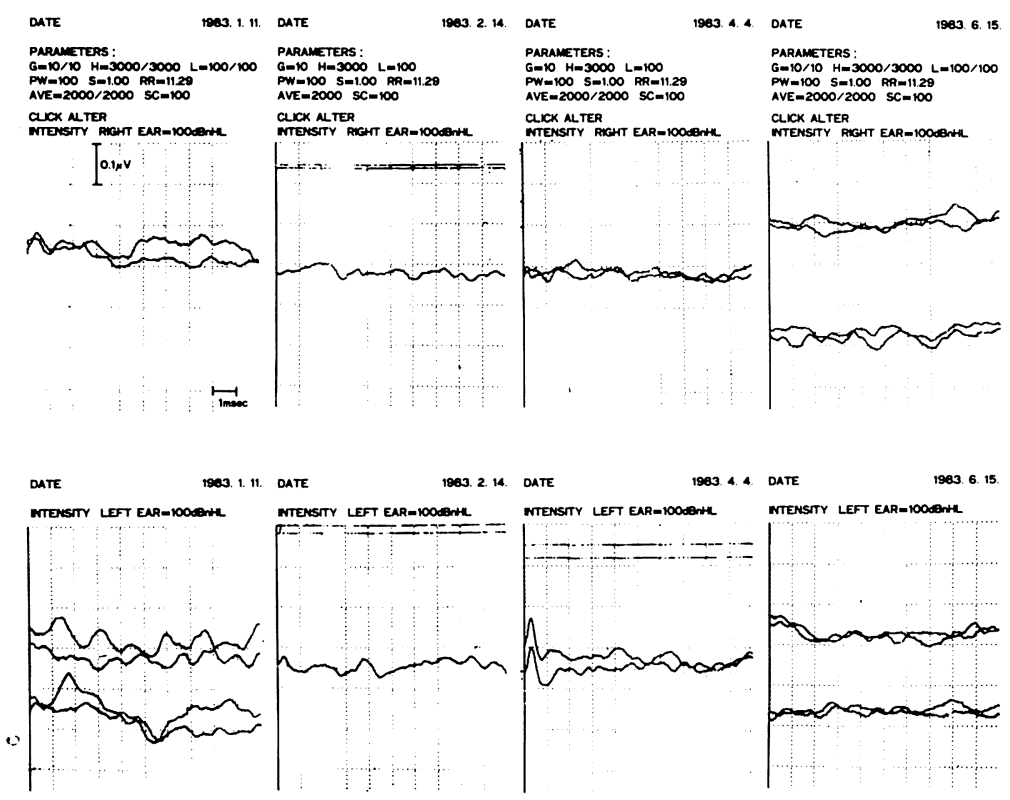

図 6 難聴児の $\mathrm{ABR}$

左上り生後11日， 2 力月， 4 力月， 6 力月 
で急峻なスロープの周波数部位では tone pip $\mathrm{ABR}$ が刺激音周波数周辺のより域值の低い部 位を反映すると述べている.また高瀬52（1987） は 500 4000 Hz の tone pipによる ABR 域值と 純音域値に相関を認めなかった。一般には tone pip による ABR は，ある程度周波数別の 聴覚機能を調べるのに有用であるという報告が 多い.

その他， high pass masking を用いた derived response による方法 ${ }^{61)}$ や notched noise による 方法62) があるが，時間がかかる，など一般へ の普及は難しいと考光られる

近年，クリックを刺激音とした $\mathrm{ABR} て ゙ も ，$ 潜時が約 $3 \mathrm{msec}$ の陰性波が低音域の残聴の指 標になるのではないかといわれてきた，真鍋 ら ${ }^{63)}$ （1982）は高度難聴児の ABR の判定にV 波の他に潜時 $3 \mathrm{msec}$ の陰性波も用いた。白石 ら ${ }^{64)}$ (1988）は高度難聴者の ABR の7.9\%に潜 時 $3 \mathrm{msec}$ 陰性波を認め, 成人例にも認められ たが幼少児が圧倒的に多く，また $500 \mathrm{~Hz}$ に残 聴のある例が殆どであったと報告した。田内 ら65）（1988）もこの波が認められた例で低音残 聴型のオージオグラムがみられたと報告した.

この潜時 $3 \mathrm{msec}$ 陰性波の存在は低音域に残聴 のあることを示しているよらではあるが，低音 残聴型でもこの波がみられない者もあり，さら に検討を要すると考えられる.

(3) 問題点について

$\mathrm{ABR}$ による乳幼児の聴力検査の有用性につ いては多くの報告や現在広く普及しているとい ら事実が証明するところである。しかし， ABR の結果と臨床経過が異なる例も時にみら れる.

Duara ら66)（1986）はリスクファクターを持 った新生児に ABR を行い，異常所見を示した 例で follow up を行ったところ, 難聴が存続し たのは27例中 4 例のみで, 23 例は後日の聴力検 查で聴力正常と判定されたと報告した。また， 沖津ら ${ }^{67)}$ (1988）は ABR で無反応の例でも， 遊戯聴力検查を行うと，高度難聴は $87.5 \%$ で残
りの $12.5 \%$ は中等度難聴だったと報告した。こ のことは，ABR と共に他の検査も総合して慎 重に判断していかなければならないといえる。

一方，他に障害を持つ子供で ABR が異常に でる場合もある、精神発達遅滞児の ABR につ いて Sohmer ら ${ }^{68)}$ （1978）はV波の欠損や潜時 の延長があったと報告, 加我69)（1982）も波形 の異常な例はなかったものの約 $41 \%$ に潜時延長 がみられたと報告した.一方, 横山ら70)（1976） は波形，域值などに異常は認めなかったとして いる。

横地ら ${ }^{71)}$ (1983) は ABR 域值が $85 \mathrm{~dB}$ 以上 の発達障害児（脳性麻㽻など）で聴性行動反応 域值を調べ，正常児域值との差が $20 \mathrm{~dB}$ 以内は $6 \% ， 21 \sim 60 \mathrm{~dB}$ が $40 \% ， 61 \mathrm{~dB}$ 以上の者は54 \%であり, ABR のV波域值よりも低い傾向に あったと報告した。このように中枢神経系に異 常のある幼児では ABR が異常にでやすく, 注 意が必要である.

III. スクリーニング検査のシステム化

以上，それぞれの時期別にどのようなスク リーニング検査が実施されてきたか歴史的に概 観してきた.これらより判断して今まで多くの 研究者がそれぞれの時期に各々異なった方法を 考案し，かなりの成果を上げてきているものの 現状ではこの方法が万能であるといえるものが 見つかっていない．またスクリーニングの対象 としている人間の聴力自体その時々の生体の状 態次第で変化してゆくものであるため小児の発 達過程の一時期にのみスクリーニング検查を実 施して事足れりといらわけにはいかない。この ような問題点から考えて難聴児早期発見診断の ためには, 新生児期から 2 歳頃まで各時期に適 したスクリーニングの為のテストバッテリーを 選び出しそれらを有機的に実施していくシステ ム作りに取り組まなければならない。

わが国においては厚生省を頂点とした行政の 指導により保健所活動のなかに聴覚スクリーニ ング検査のテストバッテリーを組み込んでいく ことが難聴児の早期発見, 専門機関への精密検 
査の早期依頼， ハビリテーションの早期開始へ の最も近道と思える. 事実, この保健所の乳幼 児検診が制度的に行われていることを利用して 横山ら ${ }^{72)}$ (1985）は infant hearing screening program（以下 IHSP）を大阪市内の 4 保健所 管内で 6 年間に渡って実施し 22,443 名中 65 名の 要精検者を選別し10名の聴力障害児を検出して いる.この際 IHSP として使用した検査はリス ク調査, 田中の聴覚発達チェックリストによる 検査 ${ }^{32)}$, 聴性行動反応検査（ewing 法）であっ た.この報告で最も注目に值するのは後日の調 査で高度聴力障害児を一例も取りこぼしていな かったといらことである.

我々はこのような保健所の健診システムを利 用した IHSPをもっと母親や家族の協力を得て できないか考えてみた．基本的にはスクリーニ ングの対象である新生児と最も接する時間の長 い母親の難聴に対する関心を高めることが最も 大切であるといら理念に立たなければならない と考える。そこでまず耳鼻咽喉科医は妊婦が受 講する母親教室の段階から難聴に関する正しい 知識の普及に関与し始めなければならない，母 子手帳には田中・新藤の聴覚発達チェックリス 卜33) が印刷されており，この教室でその内容 について教育を受けた母親が自分の子供の発育 時期に応じた聴覚の発達項目をチェックできる ようにしておく.

そのような準備段階を経て生後のスクリーニ ングへと入って行く．まず第一段階としてすべ ての新生児は出生後一週間以内に母親もしくは 産婦人科のナースによって胎内音によるスク リーニング検査を受けその反応の有無は必ず母 子手帳に記入される。保健婦活動の一部として の新生児初回家庭訪問時もしくは一カ月健診時 に難聴リスクファクター調査を実施してもらら と共に母親や家族に舌打ち音による検査の方法 を教え,この結果も母子手帳に記入させる. 以 上のことが徹底できれば三カ月健診や六力月健 診の時に今までのことをチェックでき保健所活 動の一環として要精密検査児をスクリーニング
できると思える．上記のシステムによれば多分 精密検査の必要となる対象児を取り込み過ざる 現象が起こるであろう. しかし取りこぼしが起 こることは多少経済的に問題となろらとも避け なければならない。もしこの時期に専門機関で の精密検査に持って行けるとすれば難聴児の早 期診断につながりハビリテーションを開始する 時期も手遅れにはならないと思える.

今後このような難聴時スクリーニングシステ ムをまず和歌山県下に成立させるべく行政にも 働き掛け，保健所，産婦人科，小児科も含めて 広く啓蒙活動を行っていかなければならないと 考えている.

\section{参考文献}

1) Murphy $\mathrm{KP}$ and Smyth $\mathrm{CN}$ : Response of fetus to auditory stimulation. Lancet $1: 972 \sim 973$, 1962.

2) Elliot GB and Elliot KA : Some pathological, radiological, and clinical implication of the precocious development of the human ear. Laryngoscope $74: 1160 \sim 1171,1964$.

3) Peiper A: Sinnesempindungen des Kindes vor seiner Geburt. Mschr Kinderheilk 29 : 236 $\sim 241,1924$.

4) Forbes HS and Forbes HB : Fetal sense reaction. J Comp Psychl $7:$ 353 356, 1927.

5) Sontag LW and Wallace RF : The movement response of the human fetas to sound stimuli. Child Developm 6 : 253 258, 1935.

6) Johansson B, Wedenberg E and Westin B : Mesurement of tone response by the human foetus; a preliminary report. Acta Otolaryng $57:$ 188 192, 1964.

7）荒山 喬：音刺激に対する胎児の反応. 日耳鼻 $73: 1885 \sim 1907,1970$.

8) Barden TP, Peltzman P and Graham JT : Human fetal electroenephalographic response to intrauterine acoustic signals. Am J Obst and Gynec 100 : 1128 1134, 1968.

9) Sakabe $N$, Arayama $T$ and Suzuki $T:$ Human fetal evoked response to acoustic stimulation. Acta Otolaryng Suppl $252: 29 \sim 36,1969$.

10）田口喜一郎：新生児聴覚スクリーニング。日耳 
鼻 $75: 924 \sim 936,1972$.

11）田中美郷：新生児聴力検査. 日耳鼻 補冊 5 ： $63 \sim 67,1969$.

12) Ewing IR and Ewing AW : The ascertainment of deafness in infancy and early children. J Laryng and Otol $59: 309 \sim 333,1944$.

13) Hardy JB, Dougherty A and Hardy WG : Hearing responses and audiologic screening in infant. J Pediatrics $55:$ 382 390, 1959.

14) Hardy WG, Hardy JB, Brinker $\mathrm{CH}$, et al : Auditory screening of infants. An Otol 71 : 759 766, 1962.

15) Fröding CA : Acoustic investigation of newborn infant. Acta Otolaryngol $52: 31 \sim 40$, 1960.

16) Downs MP and Sterritt GM : Identification audiometry for neonates; a preliminary report. J Aud Res 4 : 69 80, 1964.

17) Downs MP and Sterritt GM : A guide to newborn and infant hearing screening program. Arch Otolaryngol $85:$ 15 22, 1967.

18) Goldstein $R$ and Tait $C$ : Critique of neonatal hearing evaluation. J Speech and Hearing Dis $36: 3 \sim 18,1971$.

19) Shapiro I : Newborn hearing screening in a country hospital. J Speech and Hearing Dis $39: 89 \sim 92,1974$.

20）高島敬忠, 有泉基水, 川真田裕, 他 : Infant Audiometer 使用による新生児聴力検査に関す る研究. 日本新生児学会誌 $4: 66 \sim 71,1968$.

21）高木二郎, 伊藤治夫, 岡田智子: Neo-Meter による乳児聴力スクリーニングテスト。耳候 $42: 429 \sim 434,1970$.

22）鈴木篤郎, 田中美郷：幼巟難聴. 103～105頁, 医歯薬出版, 東京 1979 .

23）加藤 寛, 田中佐代子, 田端敏秀 : 胎内音に対 する新生児の聴覚反応. 耳鼻臨床 $77: 1367$ 1373, 1984.

24）加藤 寛, 田中佐代子, 田端敏秀: 胎内音に対 する新生児聴覚反応の経時的変化. Audiol Japan 28 : 744 748, 1985.

25）加藤 寛, 柏木真弓美, 九鬼佐代子, 他 : 和歌 山県御坊保健所管内における高度難聴児スク リーニングの試み. 昭和 60 年度厚生省心身障害
研究「聴覚言語障害児の療育に関する研究」ワー クショップ報告書, 19〜23頁, 1986.

26) Simmons FB and Russ FN : Automated newborn hearing screening, the crib-o-gram. Arch Otolaryngol $100: 1 \sim 7,1974$.

27) Altman MM, Shenhav R and Schaudinischky L : Semi-objective method for auditory mass screening of neonates. Acta Otolaryngol 79 : 46 50, 1975.

28）田中美郷, 阿波野安幸, 坂本正二: Neonatal Audiometer による新生児の聴性反応の観察. Audiol Japan $26: 4 ; 279 \sim 280,1983$.

29）山本賢之, 浅野公子, 小倉修二, 他 : Crib-OGram のスコアに影響を及ぼす要因について. Audiology Japan 24 : 271 272, 1981.

30）山本賢之：Crib-O-Gram による新生児の聴力 スクリーニング.日耳鼻 88 : 1132〜1140, 1985.

31）鈴木重忠, 能登谷晶子: 入眠時聴性開眼反応. Audiol Japan $23: 26 \sim 33,1980$.

32）田中美郷, 小林はるよ, 新藤美津子, 他 : 乳児 の聴覚発達検査とその臨床および難聴児早期ス クリーニングへの応用. Audiol Japan 21:52 $\sim 73,1978$.

33) Junker KS, Barr B, Maliniemi S, et al : BOEL screening; a program for early detection of communicative disorders. Audiology $17: 51 \sim 61$, 1978.

34) Barr B, Junker KS and Svärd M : Early discovery of hearing impairment; a clinical evaluation of the BOEL test. Audiology 17 : $62 \sim 67,1978$.

35）宮崎 和, 長野 操, 横山不二子 : 乳児聴力の 実用的検査法について. Audiol Japan 12:229 $\sim 230,1969$.

36) Suzuki $\mathrm{T}$ and Ogiba $\mathrm{Y}$ : Conditioned orientation reflex audiometry. Arch Otolaryngol 74 : 192 198, 1961.

37）古賀慶次郎：集団を対象とした小児の聴力検査 について. 小児医学 $16: 5 ; 907 〜 928,1983$.

38）野中信之, 川野通夫, 山本悦生, 他 : ことばの テスト絵本による囁語法聴力検査の意義. Audiology Japan 25 : 525 526, 1982.

39）長谷川茂, 奈良章子, 大杉純子, 他：単語によ る幼児の選別聴力検査（第 4 報）. Audiology 
Japan $19: 567 \sim 568,1976$.

40) Krumholtz A, et al : Maturaion of the brainstem auditory evoked potential in premature infants. Electroencephalogr Clin Neurophysiol $62: 124 \sim 134,1985$.

41) Galambos R and Hecox $K$ : Clinical application of the auditory brainstem response. Otolaryngol Clin North Am 11 : 709 722, 1978.

42) Hecox K and Burkhard R:Developmental dependencies of the human auditory evoked response. Ann NY Acad Sci 388 : 538 556, 1982.

43) Starr A, Amlie RN, Martin WH, et al : Developmental of auditory function in newborn infants revealed by auditory brainstem potentials. Pediatr $60: 831 \sim 839,1977$.

44) Lary S, Briassoulis G, de Vries L, et al : Hearing threshold in preterm and term infants by auditory brainstem response. J Pediatr 107 : 593 599, 1985.

45) Kaga K and Tanaka Y : Auditory brainstem response and behavioral audiometry; developmental correlates. Arch Otolaryngol $106: 564$ $\sim 566,1980$.

46) Mokotoff $B$, Schulman-Galambos $C$ and Galambos $\mathrm{R}$ : Brainstem auditory evoked responses in children. Arch Otolaryngol $103: 38 \sim 43$, 1977.

47) Morgan D Zimmerman $\mathrm{M}$ and Dubno $\mathrm{J}$ : Auditory brain stem response characteristics in the full-term newborn infant. Ann Otol Rhinol Laryngol $96: 142 \sim 151,1987$.

48）加我君孝, 田中美郷 : 乳幼児の発達と聴性脳幹 反応および聴性行動反応の変化. 脳と発達 10 : 284 290, 1978.

49）宮嶋佳世子, 石田正人, 野末道彦 : 新生児集中 治療室における早産児の ABR. 日耳鼻 88 ： 1666 1671, 1985.

50) Zimmerman MC, Morgan DE and Dubno JR : Auditory brain stem evoked response characteristics in developing infants. Ann Otol Rhinol Laryngol $96: 291 \sim 299,1987$.

51) Collet L, Morgan A, Soares I, et al : Maturation changes in the intensity latency relation of the brainstem auditory evoked potentials in humans. Acta Otolaryngol 105 : 473 476, 1988.

52）高瀬二郎：クリック刺激に対する聴性脳幹反応 による聴力推定の試み. 日耳鼻 $90: 202 \sim 210$, 1987.

53）船井洋光，堀内康治：クリック刺激による ABR と蝸牛機能との関係. Audiology Japan $29: 43 \sim 50,1986$

54）小寺一興, 山根 仁, 山田 修, 他 : 聴性脳幹 反応による会話域聴覚域値の測定.耳鼻臨床 70 : 207〜214, 1977.

55）大西信治郎：低周波数の検査. 聴性脳幹反応 その基礎と応用（船坂宗太郎，大西信次郎編） 211〜216頁, メジカルビュー社, 東京, 1985 .

56) Suzuki T, Hirai $Y$, et al : Auditory brain stem responses to pure tone stimuli. Scand Audiol $6: 51 \sim 56,1977$.

57）小寺一興 : 聴性脳幹反応による幼少児の他覚的 聴力検査. 日耳鼻 $84: 139 \sim 145,1981$.

58) 大西信治郎, 他 : 増幅器フィルターの検討と神 奈川こども医療センター ABR 症例の行動聴力 との比較. 耳鼻 29 補 $2: 679 \sim 692,1983$.

59) Hayes D and Jerger J : Auditory brain stem response (ABR) to tone-pips; results in normal and hearing-impaired subjects. Scand Audiol $11: 133 \sim 142,1982$

60）堀内康治，船井洋光：トーンピップ刺激による ABR の周波数同調曲線一感音難聴例の検討. Audiology Japan $31:$ 369 370, 1988.

61) Don M, Eggermont JJ, et al : Reconstruction of the audiogram using brainstem responses and high pass noise masking. Ann Otol Rhinol Laryngol 88 Suppl $57:$ 1 20, 1979.

62) Picton TW, Quellette J, et al : Brainstem evoked potentials to tone pips in notched noise. J Otolaryngol $8: 289 \sim 314,1979$.

63）真鍋敏毅，西沢伸志，木場興次，他：高度感音 難聴児における ABR 検査の信頼性. Audiology Japan 25 : 433 434, 1982.

64）白石君男, 曽田豊二, 加藤寿彦: ABR 記録時 に出現する潜時 $3 \mathrm{msec}$ の陰性波について. Audiology Japan 31 : 123 132, 1988.

65）田内 光, 西澤典子, 米本 清, 他 : 高度難聴 の ABR にお忷る潜時 $3 \mathrm{msec}$ の陰性波につい 
て. Audiology Japan $31: 377 \sim 378,1988$.

66) Duara S, Suter CM, Bessard KK, et al : Neonatal screening with auditory brainstem responses; results of follow-up audiometry and risk factor evaluation. J Pediatr 108 : 276 281, 1986.

67）沖津卓二, 堀富美子：ABR 無反応症例の追跡 結果. Audiology Japan 31 : 375 376, 1988.

68) Sohmer $\mathrm{H}$ and Student $\mathrm{M}$ : Auditory nerve and brain stem evoked responses in normal, acoustic minimal brain dysfunction and psychomotor retarded children. Electroencephalogr Clin Neuro-physiol 44 : 380, 1978.

69）加我牧子: 精神発達遅滞児の発達と聴性行動反 応および聴性脳幹反応の関係について。日本小 児科学会雑誌 $86: 98 \sim 104,1982$.
70）横山俊彦, 小上芳春, 山田篤子, 他 : 主として 精神発達遅帯児に対する聴性脳幹反応の臨床的 応用. 日耳鼻 $79: 1323,1976$.

71）横地健治, 北住映二, 榎本省子, 他 : 発達障害 児における末梢聴力障害型聴性脳幹反応と聴性 行動反応一聴力評価法としての聴性脳幹反応の 限界一. 日本小児科学会雑誌 $87: 1435 \sim 1443$, 1983.

72）横山俊彦, 橋口久美子, 岸本キクエ, 他 : 保健 所健診での聴力障害児早期発見のためのスク リーニングー6 年間の retrospective study一. 日本公衛誌 $32: 12 ; 707 \sim 717,1985$.

$$
\left(\begin{array}{l}
\text { 別刷請求先 : 加藤 寛 } \\
\text { 厂640 和歌山市七番丁 } 27 \\
\text { 和歌山県立医科大学耳鼻咽喉科学教室 }
\end{array}\right)
$$

